\title{
Syntheses, Crystal Structures, Antimicrobial Activity and Thermal Behavior of Copper(II) Complexes Derived from 1-Naphthylacetic Acid and Diamines
}

\author{
Ling-Wei Xue, ${ }^{1,{ }^{*}}$ Chen Chen, ${ }^{2}$ Gan-Qing Zhao ${ }^{1}$ and Wei-Chun Yang1 \\ ${ }^{1}$ College of Chemistry and Chemical Engineering, Pingdingshan University, Pingdingshan 467000, P.R. China \\ ${ }^{2}$ Rock and Mineral Testing Center of Henan Province, Zhengzhou 450000, P.R. China \\ *Corresponding author: E-mail: pdsuchemistry@163.com
}

Received: 06-15-2019

\begin{abstract}
Two copper(II) complexes, $\left[\mathrm{CuL}_{2}(\mathrm{EA})\right](\mathbf{1})$ and $\left[\mathrm{Cu}_{2} \mathrm{~L}_{4}(\mathrm{PA})_{2}\right] \cdot 2 \mathrm{H}_{2} \mathrm{O}\left(\mathbf{2} \cdot 2 \mathrm{H}_{2} \mathrm{O}\right)$, where $\mathrm{L}$ is 1-naphthylacetate, EA is $\mathrm{N}, \mathrm{N}$-diethylethane-1,2-diamine, PA is propane-1,3-diamine, have been prepared and characterized. Structures of the complexes have been characterized by single-cyrstal X-ray diffraction. Complex $\mathbf{1}$ is a mononuclear copper(II) compound, with the $\mathrm{Cu}$ atoms coordinated in square planar geometry. Complex $2 \cdot 2 \mathrm{H}_{2} \mathrm{O}$ is a centrosymmetric dinuclear copper(II) compound, with the $\mathrm{Cu}$ atoms coordinated in square pyramidal geometry. Single crystals of the complexes are stabilized by hydrogen bonds. The effects of the compounds on the antimicrobial activity against Staphylococcus aureus, Escherichia coli, and Candida albicans, as well as thermal behavior of the complexes were studied.
\end{abstract}

Keywords: Copper complex; crystal structure; hydrogen bonding; antimicrobial activity; thermal property

\section{Introduction}

Carboxylic acids are a kind of interesting ligands for the preparation of metal complexes. ${ }^{1}$ Copper is a very important element in biological systems, functions as the active site of hydrolytic enzymes, such as $\mathrm{Cu}-\mathrm{Zn}$ superoxide dismutase. $^{2}$ Copper complexes with carboxylate ligands have been widely reported for their versatile structures and biological applications. ${ }^{3}$ Intriguingly, the copper(II) complexes were shown to be significantly more potent than the metal free chelate, leading to the suggestion that the metal complex was the biologically active species. ${ }^{4}$ Copper(II) complexes are known to play a significant role either in naturally occurring biological systems or as pharmacological agents. ${ }^{5}$ 1-Naphthylacetic acid is structurally similar to carboxylic acids. However, very few copper complexes derived from 1-naphthylacetic acid have been reported so far. In the present paper, two new copper(II) complexes, $\left[\mathrm{CuL}_{2}(\mathrm{EA})\right](\mathbf{1})$ and $\left[\mathrm{Cu}_{2} \mathrm{~L}_{4}(\mathrm{PA})_{2}\right] \cdot 2 \mathrm{H}_{2} \mathrm{O}(\mathbf{2}$. $2 \mathrm{H}_{2} \mathrm{O}$ ), where $\mathrm{L}$ is 1 -naphthylacetate, $\mathrm{EA}$ is $\mathrm{N}, \mathrm{N}$-diethylethane-1,2-diamine, PA is propane-1,3-diamine, are reported.

\section{Experimental}

\section{1. Materials and Measurements}

Commercially available 1-naphthylacetic acid, $\mathrm{N}, \mathrm{N}$-diethylethane-1,2-diamine, and propane-1,3-diamine were purchased from Aldrich and used without further purification. Other solvents and reagents were made in China and used as obtained. C, $\mathrm{H}$ and $\mathrm{N}$ elemental analyses were performed with a Perkin-Elmer elemental analyser. Infrared spectra were recorded on a Nicolet AVATAR 360 spectrometer as $\mathrm{KBr}$ pellets in the $4000-400 \mathrm{~cm}^{-1}$ region. Thermal stability analysis was performed on a Perkin-Elmer Pyris Diamond TG-DTA thermal analyses system.

\section{2. Synthesis of $\left[\mathrm{CuL}_{2}(\mathrm{EA})\right]$ (1)}

An aqueous solution $(10 \mathrm{~mL})$ of $\mathrm{CuSO}_{4} \cdot 5 \mathrm{H}_{2} \mathrm{O}(0.10$ $\mathrm{mmol}, 24.9 \mathrm{mg}$ ) was added to an aqueous solution $(10 \mathrm{~mL})$ of 1-naphthylacetic acid $(0.20 \mathrm{mmol}, 37.2 \mathrm{mg})$ and $N, N$-diethylethane-1,2-diamine $(0.20 \mathrm{mmol}, 23.2 \mathrm{mg})$ with stirring. The mixture was stirred for $1 \mathrm{~h}$ at ambient condition 
to give a clear blue solution. The resulting solution was allowed to stand in air for several days. Blue block-shaped crystals suitable for X-ray single crystal analysis were formed at the bottom of the vessel. The isolated product was washed three times with water, and dried in a vacuum over anhydrous $\mathrm{CaCl}_{2}$. For $\mathrm{C}_{30} \mathrm{H}_{34} \mathrm{CuN}_{2} \mathrm{O}_{4}$ : anal. calcd., \%: C, 65.60; H, 6.23; N, 5.09. Found, \%: C, 65.71; H, 6.32; N, 4.98. IR data $\left(v, \mathrm{~cm}^{-1}\right): 3267,1590,1460,1388,1258,1119$, 1043, 782, 718, 630, 537, 465.

\section{3. Synthesis of $\left[\mathrm{Cu}_{2} \mathrm{~L}_{4}(\mathrm{PA})_{2}\right] \cdot 2 \mathrm{H}_{2} \mathrm{O}$}

\section{$\left(2 \cdot 2 \mathrm{H}_{2} \mathrm{O}\right)$}

This complex was prepared by the same method as that described for 1, but with $N, N$-diethylethane-1,2-diamine replaced by propane-1,3-diamine $(0.20 \mathrm{mmol}, 14.2$ mg). For $\mathrm{C}_{54} \mathrm{H}_{60} \mathrm{Cu}_{2} \mathrm{~N}_{4} \mathrm{O}_{10}$ : anal. calcd., \%: C, 61.64; $\mathrm{H}$, 5.75; N, 5.32. Found, \%: C, 61.50; H, 5.82; N, 5.23. IR data $\left(v, \mathrm{~cm}^{-1}\right): 3309,3229,1616,1367,1270,1173,1110,1026$, $912,781,710,634,546,486$.

\section{4. X-Ray Diffraction}

Diffraction intensities for the complexes were collected at 298(2) K using a Bruker D8 VENTURE PHOTON diffractometer with MoKa radiation $(1=0.71073 \AA)$. The collected data were reduced using SAINT, ${ }^{6}$ and multi-scan absorption corrections were performed using SADABS. ${ }^{7}$ The structures were solved by direct methods and refined against $F^{2}$ by full-matrix least-squares methods using SHELXTL. ${ }^{8}$ All of the non-hydrogen atoms were refined anisotropically. The water $\mathrm{H}$ atoms in $\mathbf{2} \cdot 2 \mathrm{H}_{2} \mathrm{O}$ were locat- ed from a difference Fourier map and refined isotropically, with $\mathrm{O}-\mathrm{H}$ and $\mathrm{H} \cdots \mathrm{H}$ distances restainred to $0.85(1)$ and 1.37(2) $\AA$, respectively. The remaining $\mathrm{H}$ atoms were placed in idealized positions and constrained to ride on their parent atoms. The low data completeness of complex 1 (76.2\%) is due to the poor-quality data of the crystal. The crystallographic data for the complexes are summarized in Table 1.

\section{5. Antimicrobial Assay}

Qualitative determination of antimicrobial activity was done using the disk diffusion method as described in the literature. ${ }^{9}$ Suspensions in sterile peptone water from 24-h cultures of microorganisms were adjusted to $0.5 \mathrm{Mc}$ Farland. Muller-Hinton Petri dishes of $90 \mathrm{~mm}$ were inoculated using these suspensions. Paper disks $(6 \mathrm{~mm}$ in diameter) containing $10 \mu \mathrm{L}$ of the substance to be tested (at a concentration of $2048 \mu \mathrm{g} \mathrm{mL}^{-1}$ in DMSO) were placed in a circular pattern in each inoculated plate. Incubation of the plates was done at $37^{\circ} \mathrm{C}$ for $18-24 \mathrm{~h}$. Reading of the results was done by measuring the diameters of the inhibition zones generated by the test substance. Tetracycline was used as a reference substance. Determination of MIC was done using the serial dilutions in liquid broth method. The materials used were 96-well plates, suspensions of microorganism (0.5 McFarland), Muller-Hinton broth (Merck) and stock solutions of each substance to be tested (2048 $\mu \mathrm{g}$ $\mathrm{mL}^{-1}$ in DMSO). The following concentrations of the substances to be tested were obtained in the 96-well plates: $1024,512,256,128,64,32,16,8,4$ and $2 \mu \mathrm{g} \mathrm{mL}^{-1}$. After incubation at $37^{\circ} \mathrm{C}$ for $18-24 \mathrm{~h}$, the MIC for each tested substance was determined by microscopic observation of

Table 1. Crystallographic and experimental data for complexes $\mathbf{1}$ and $\mathbf{2} \cdot 2 \mathrm{H}_{2} \mathrm{O}$

\begin{tabular}{|c|c|c|}
\hline & 1 & $2 \cdot 2 \mathrm{H}_{2} \mathrm{O}$ \\
\hline Formula & $\mathrm{C}_{30} \mathrm{H}_{34} \mathrm{CuN}_{2} \mathrm{O}_{4}$ & $\mathrm{C}_{54} \mathrm{H}_{60} \mathrm{Cu}_{2} \mathrm{~N}_{4} \mathrm{O}_{10}$ \\
\hline FW & 550.1 & 1052.1 \\
\hline Crystal system & Monoclinic & Monoclinic \\
\hline Space group & $P 2_{1} / c$ & $P 2_{1} / c$ \\
\hline$a / \AA$ & $13.496(2)$ & $11.474(2)$ \\
\hline$b / \AA$ & $9.111(1)$ & $27.474(2)$ \\
\hline$c / \AA$ & $22.411(2)$ & $8.409(1)$ \\
\hline$\beta /^{\circ}$ & $97.331(2)$ & $101.937(2)$ \\
\hline$V / \AA^{3}$ & $2733.2(6)$ & $2593.3(6)$ \\
\hline$Z$ & 4 & 2 \\
\hline$\mu / \mathrm{mm}^{-1}(\mathrm{Mo}-\mathrm{K} \alpha)$ & 0.836 & 0.881 \\
\hline$D_{c} / \mathrm{g} \mathrm{cm}^{-3}$ & 1.337 & 1.347 \\
\hline Reflections/parameters & $3873 / 336$ & $4493 / 322$ \\
\hline Independent reflections & 1669 & 2316 \\
\hline Restraints & 0 & 3 \\
\hline$F(000)$ & 1156 & 1100 \\
\hline Goodness of fit on $F^{2}$ & 1.007 & 1.011 \\
\hline$R_{1}, w R_{2}[I \geq 2 \sigma(I)]^{\mathrm{a}}$ & $0.0648,0.1068$ & $0.0647,0.1298$ \\
\hline$R_{1}, w R_{2}$ (all data) $)^{\mathrm{a}}$ & $0.2245,0.1547$ & $0.1625,0.1599$ \\
\hline Largest diff. peak and hole/e $\AA^{-3}$ & $0.409,-0.728$ & $0.845,-0.500$ \\
\hline
\end{tabular}


microbial growth. It corresponds to the well with the lowest concentration of the tested substance where microbial growth was clearly inhibited.

\section{Results and Discussion}

\section{1. Chemistry}

The two copper complexes were prepared by the reaction of $\mathrm{CuSO}_{4} \cdot 5 \mathrm{H}_{2} \mathrm{O}$, 1-naphthylacetic acid and $\mathrm{N}, \mathrm{N}$-diethylethane-1,2-diamine in a molar ratio of 1:2:2 in aqueous solution. Single crystals of the complexes are stable in air at room temperature. The complexes are soluble in water, DMSO, methanol and ethanol, but insoluble in dichloroform and chloroform. 1-Naphthylacetate ligand usually adopt bidentate coordination mode with copper ion, ${ }^{10}$ with only two reported examples of monodentate coordination mode. ${ }^{11}$

\section{2. IR Spectra}

The infrared spectra of the complexes were consistent with their structures as determined by X-ray diffraction. Features corresponding to naphthyl and benzene ring puckering exist in the region between 800 and $600 \mathrm{~cm}^{-1}$. Asymmetric and symmetric $\mathrm{C}-\mathrm{O}$ stretching modes of the fully deprotonated, ligated carboxylate groups were substantiated by strong, broadened bands at 1590 and 1389 $\mathrm{cm}^{-1}$ for complex $\mathbf{1}$, and 1618 and $1369 \mathrm{~cm}^{-1}$ for complex $2 \cdot 2 \mathrm{H}_{2} \mathrm{O} .{ }^{12}$ The lack of bands in the region of about 1710 $\mathrm{cm}^{-1}$ is indicative of complete deprotonation of all carboxylate groups in both complexes.

\section{3. Structure Description of the Complexes}

The molecular structures of complexes are shown in Figures 1 and 2. Selected bond lengths and angles are listed in Table 2. Complex 1 is a mononuclear copper(II) compound. The $\mathrm{Cu}$ atom in the complex is coordinated by two $\mathrm{N}$ atoms of the diamines, and two carboxylate $\mathrm{O}$ atoms from two L, forming square planar geometry. Complex 2 . $2 \mathrm{H}_{2} \mathrm{O}$ is a centrosymmetric dinuclear copper(II) compound, and contains two water molecules of crystallization. The $\mathrm{Cu}$ atoms in the complex are coordinated by the $\mathrm{N}$ atoms of the diamines, and the carboxylate $\mathrm{O}$ atoms from L, forming square pyramidal geometry. The bond lengths related to the $\mathrm{Cu}$ atoms in both complexes are similar to those observed in comparative copper complexes with carboxylate and amine ligands. ${ }^{11,13}$ The square planar coordination of complex 1 and the basal plane of the square pyramidal coordination of complex $2 \cdot 2 \mathrm{H}_{2} \mathrm{O}$ are somewhat distorted, as evidenced from the coordinate bond angles, ranging from $85.3(2)$ to $93.6(2)^{\circ}$ for the cis angles and from 167.3(3) to $169.0(3)^{\circ}$ for the trans angles for $\mathbf{1}$, and from $88.7(2)$ to $93.7(2)^{\circ}$ for the cis angles and from 162.4(2) to $168.9(2)^{\circ}$ for the trans angles for 2 .
In the crystal structures of the complexes (Figure 3 for $\mathbf{1}$ and Figure 4 for 2), the molecules are linked through intermolecular $\mathrm{N}-\mathrm{H} \cdots \mathrm{O}$ and $\mathrm{O}-\mathrm{H} \cdots \mathrm{O}$ hydrogen bonds (Table 3), to form 1D chains.

Table 2. Selected bond lengths $(\AA)$ and angles $\left(^{\circ}\right)$ for $\mathbf{1}$ and $\mathbf{2} \cdot 2 \mathrm{H}_{2} \mathrm{O}$

\begin{tabular}{|c|c|c|c|}
\hline \multicolumn{4}{|c|}{1} \\
\hline $\mathrm{Cu} 1-\mathrm{O} 2$ & $2.000(5)$ & $\mathrm{Cu} 1-\mathrm{O} 3$ & $1.965(5)$ \\
\hline $\mathrm{Cu} 1-\mathrm{N} 1$ & $2.046(5)$ & $\mathrm{Cu} 1-\mathrm{N} 2$ & $1.984(5)$ \\
\hline $\mathrm{O} 2-\mathrm{Cu} 1-\mathrm{N} 1$ & 93.74(17) & $\mathrm{O} 2-\mathrm{Cu} 1-\mathrm{N} 2$ & $168.90(18)$ \\
\hline $\mathrm{N} 1-\mathrm{Cu} 1-\mathrm{N} 2$ & $90.6(2)$ & $\mathrm{O} 2-\mathrm{Cu} 1-\mathrm{O} 3$ & $88.72(15)$ \\
\hline $\mathrm{N} 1-\mathrm{Cu} 1-\mathrm{O} 3$ & $162.43(18)$ & $\mathrm{N} 2-\mathrm{Cu} 1-\mathrm{O} 3$ & $90.19(17)$ \\
\hline \multicolumn{4}{|c|}{$2 \cdot 2 \mathrm{H}_{2} \mathrm{O}$} \\
\hline $\mathrm{Cu} 1-\mathrm{O} 2$ & $1.955(3)$ & $\mathrm{Cu} 1-\mathrm{O} 3$ & $2.002(4)$ \\
\hline $\mathrm{Cu} 1-\mathrm{N} 1$ & $1.983(5)$ & $\mathrm{Cu} 1-\mathrm{N} 2$ & $1.984(4)$ \\
\hline $\mathrm{Cu} 1-\mathrm{O} 3^{\# 1}$ & $2.467(5)$ & & \\
\hline $\mathrm{O} 3-\mathrm{Cu} 1-\mathrm{N} 2$ & $167.3(3)$ & $\mathrm{O} 3-\mathrm{Cu} 1-\mathrm{O} 2$ & $90.6(2)$ \\
\hline $\mathrm{N} 2-\mathrm{Cu} 1-\mathrm{O} 2$ & $93.6(2)$ & $\mathrm{O} 3-\mathrm{Cu} 1-\mathrm{N} 1$ & $92.8(2)$ \\
\hline $\mathrm{N} 2-\mathrm{Cu} 1-\mathrm{N} 1$ & $85.3(2)$ & $\mathrm{O} 2-\mathrm{Cu} 1-\mathrm{N} 1$ & $169.0(3)$ \\
\hline $\mathrm{O}^{\# 1}-\mathrm{Cu} 1-\mathrm{N} 1$ & $115.0(3)$ & $\mathrm{O} 3^{\# 1-C u} 1-\mathrm{N} 2$ & $84.5(3)$ \\
\hline $\mathrm{O} 3^{\# 1-C u} 1-\mathrm{O} 2$ & $84.4(3)$ & $\mathrm{O} 3^{\# 1-C u} 1-\mathrm{O} 3$ & $82.6(3)$ \\
\hline
\end{tabular}

Table 3. Geometrical parameters for hydrogen bonds

\begin{tabular}{|c|c|c|c|c|}
\hline Hydrogen bonds & D-H $(\AA)$ & $\mathrm{H} \cdots A(\AA)$ & $D \cdots A(\AA)$ & $D-\mathrm{H} \cdots A\left({ }^{\circ}\right)$ \\
\hline \multicolumn{5}{|l|}{1} \\
\hline $\mathrm{N} 2-\mathrm{H} 2 \mathrm{~B} \cdots \mathrm{O} 1^{\# 1}$ & 0.90 & 2.14 & $2.991(10)$ & 157 \\
\hline $\mathrm{N} 2-\mathrm{H} 2 \mathrm{~A} \cdots \mathrm{O} 4^{\# 2}$ & 0.90 & 2.09 & $2.946(8)$ & 158 \\
\hline \multicolumn{5}{|l|}{$2 \cdot 2 \mathrm{H}_{2} \mathrm{O}$} \\
\hline $\mathrm{O} 5-\mathrm{H} 5 \mathrm{~B} \cdots \mathrm{O} 4^{\# 3}$ & $0.85(1)$ & $2.03(3)$ & $2.780(8)$ & $148(5)$ \\
\hline $\mathrm{N} 2-\mathrm{H} 1 \mathrm{~B} \cdots \mathrm{O} 2^{\# 4}$ & 0.90 & 2.25 & $3.080(6)$ & 153 \\
\hline $\mathrm{N} 1-\mathrm{H} 2 \mathrm{~B} \cdots \mathrm{O} 1^{\# 3}$ & 0.90 & 2.16 & $2.971(6)$ & 149 \\
\hline $\mathrm{N} 1-\mathrm{H} 2 \mathrm{~A} \cdots \mathrm{O} 5$ & 0.90 & 2.25 & $3.119(9)$ & 162 \\
\hline
\end{tabular}

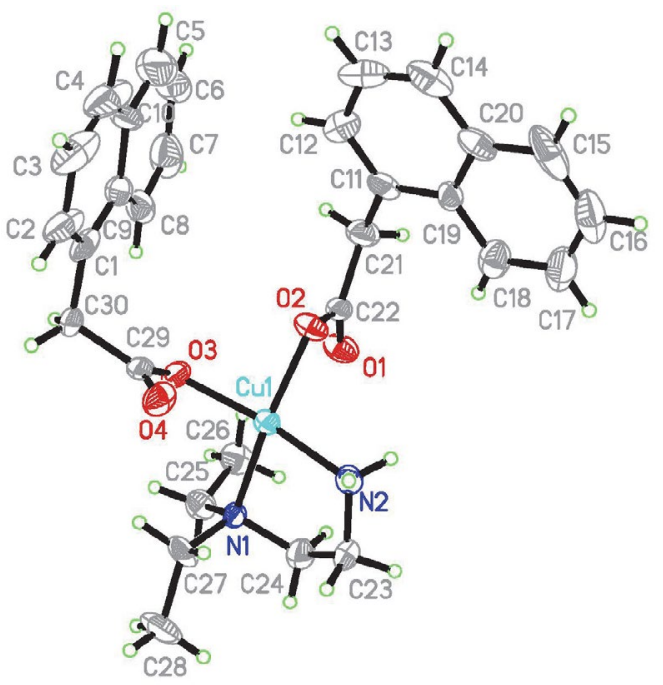

Figure 1. Molecular structure of $\mathbf{1}$ at $30 \%$ probability displacement. 


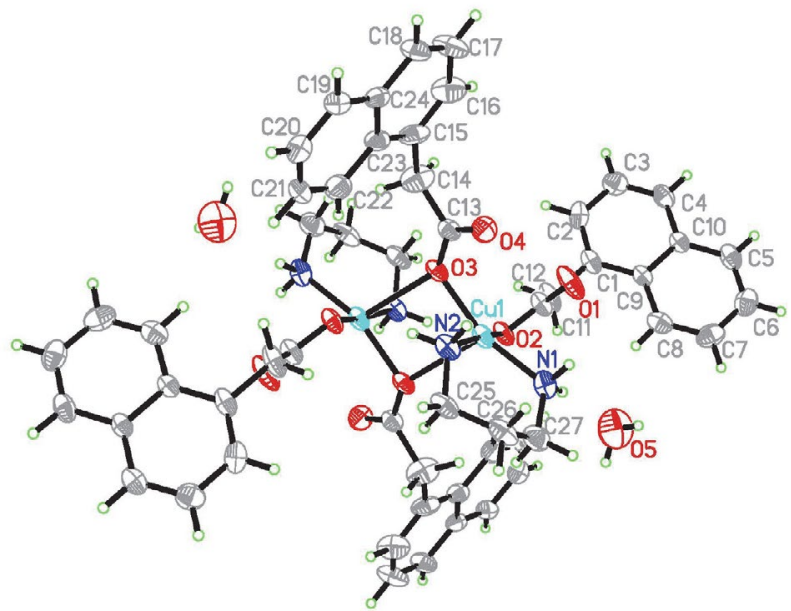

Figure 2. Molecular structure of $\mathbf{2} \cdot 2 \mathrm{H}_{2} \mathrm{O}$ at $30 \%$ probability displacement.

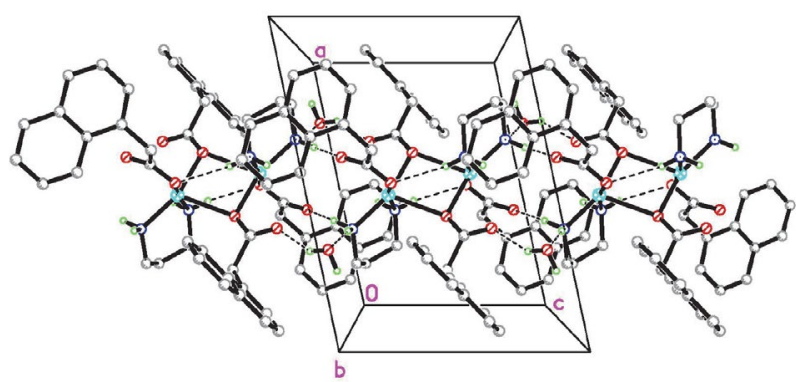

Figure 3. Molecular packing of $\mathbf{1}$, viewed along the $a$ axis. Hydrogen bonds are drawn as dashed lines. Hydrogen atoms not related to hydrogen bonds are omitted for clarity.

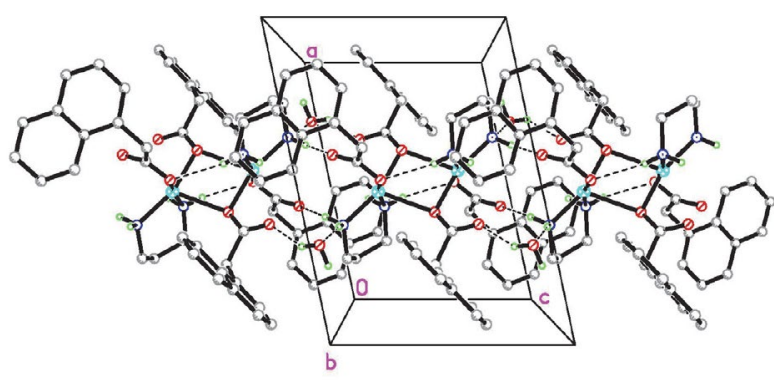

Figure 4. Molecular packing of $\mathbf{2} \cdot 2 \mathrm{H}_{2} \mathrm{O}$, viewed along the $b$ axis. Hydrogen bonds are drawn as dashed lines. Hydrogen atoms not related to hydrogen bonds are omitted for clarity.

\section{4. Thermal Stability}

Differential thermal (DT) and thermal gravimetric analyses (TGA) were conducted to examine the stability of the complexes. For 1 (Figure 5), the first step started at 166 ${ }^{\circ} \mathrm{C}$ and completed at $320^{\circ} \mathrm{C}$, corresponding to the loss of the $\mathrm{N}, \mathrm{N}$-diethylethane-1,2-diamine ligand and one 1-naphthylacetate ligand. The observed weight loss of $53.8 \%$ is close to the calculated value of $54.5 \%$. The second step, from $320^{\circ} \mathrm{C}$ to $526^{\circ} \mathrm{C}$, corresponds to the loss of the other 1-naphthylacetate ligand and the formation of the final product $(\mathrm{CuO})$. The observed weight loss of $32.1 \%$ in this step is close to the calculated value of $30.7 \%$. For $2 \cdot 2 \mathrm{H}_{2} \mathrm{O}$ (Figure 6), the first step slowly started at about $50{ }^{\circ} \mathrm{C}$ and was completed at $128{ }^{\circ} \mathrm{C}$, corresponding to the loss of the lattice water molecule. The observed weight loss of $1.8 \%$ is close to the calculated value of $1.7 \%$. The second step started at about $128{ }^{\circ} \mathrm{C}$ and was completed at $350{ }^{\circ} \mathrm{C}$, corresponding to the loss of the propane-1,3-diamine ligand and one 1-naphthylacetate ligand. The observed weight loss of $49.8 \%$ is close to the calculated value of $49.2 \%$. The third step, from $350{ }^{\circ} \mathrm{C}$ to $575^{\circ} \mathrm{C}$, corresponds to the loss of the other 1-naphthylacetate ligand and the formation of the final product $(\mathrm{CuO})$. The observed weight loss of $33.9 \%$ in this step is close to the calculated value of $32.1 \%$.

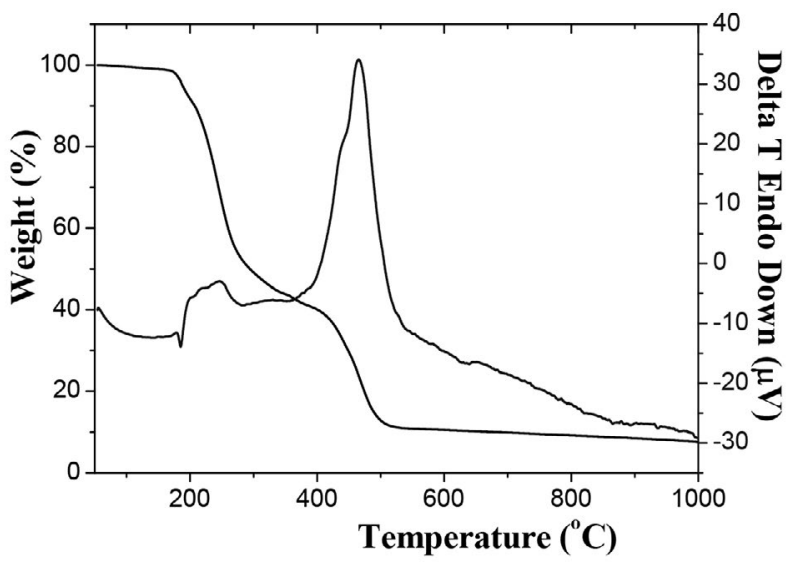

Figure 5. DT-TGA curve of $\mathbf{1}$.

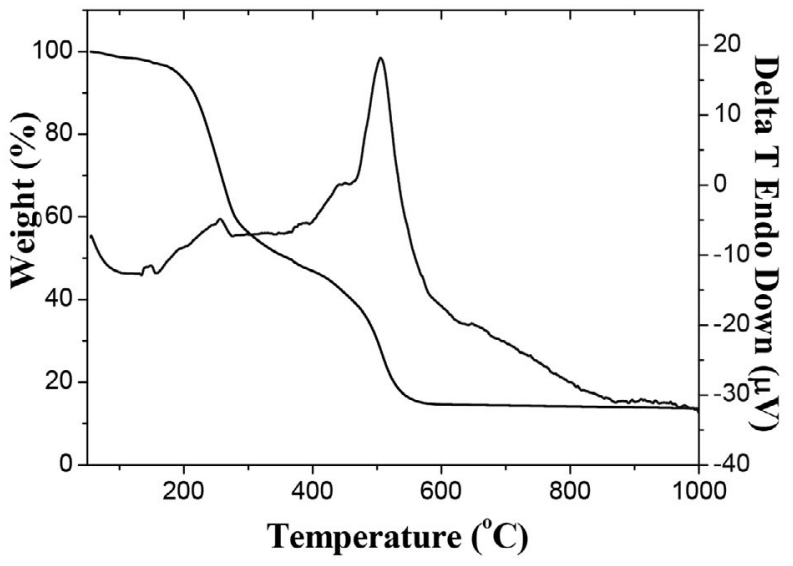

Figure 6. DT-TGA curve of $\mathbf{2} \cdot 2 \mathrm{H}_{2} \mathrm{O}$.

\section{5. Antimicrobial Activity}

The antimicrobial activity results are summarized in Table 4. A comparative study of minimum inhibitory concentration (MIC) values of 1-naphthylacetic acid, $\mathrm{N}, \mathrm{N}$-diethylethane-1,2-diamine, propane-1,3-diamine, and the complexes indicates that the copper complexes have better activity than the free ligands. Generally, this is caused by the greater lipophilic nature of the complexes than the ligand. 
Table 4. MIC values $\left(\mu \mathrm{gL}^{-1}\right)$ for the antimicrobial activities

\begin{tabular}{lccc}
\hline Compounds & Staphylococcus aureus & Escherichia coli & Candida albicans \\
\hline 1-naphthylacetic acid & 64 & 128 & $>512$ \\
$N, N$-diethylethane-1,2-diamine & 128 & $>512$ & $>512$ \\
propane-1,3-diamine & 128 & $>512$ & $>512$ \\
$\mathbf{1}$ & 0.5 & 2.0 & 32 \\
$\mathbf{2} \cdot 2 \mathrm{H}_{2} \mathrm{O}$ & 0.5 & 2.0 & 32 \\
Tetracycline & 0.32 & 2.12 & $>1024$ \\
\hline
\end{tabular}

Such increased activity of the metal chelates can be explained on the basis of chelating theory. ${ }^{14}$ On chelating, the polarity of the metal atoms will be reduced to a greater extent due to the overlap of the ligand orbital and partial sharing of positive charge of the metal atoms with donor atoms. Further, it increases the delocalization of $p$-electrons over the whole chelate ring and enhances the lipophilicity of the complexes. This increased lipophilicity enhances the penetration of the complexes into lipid membrane and blocks the metal binding sites on enzymes of microorganisms.

From the results, it is obvious that the two complexes have higher antibacterial and antifungal activities against Staphylococcus aureus, Escherichia coli, and Candida albicans when compared to the free ligands. The two complexes have in general the same activities against all the bacteria and fungi strains. The best inhibition on Staphylococcus aureus is indicated by the MIC values of $0.5 \mu \mathrm{g} \mathrm{mL} \mathrm{m}^{-1}$, which is similar to tetracycline. The complexes have strong activity against $E s c h$ erichia coli, which is even comparable to tetracycline. It is interesting that both complexes have medium activity against Candida albicans, which is rarely seen in metal complexes.

\section{Supplementary Material}

CCDC-957485 (1) and $957486\left(2 \cdot 2 \mathrm{H}_{2} \mathrm{O}\right)$ contain the supplementary crystallographic data for this paper. These data can be obtained free of charge at http://www. ccdc.cam.ac.uk/const/retrieving.html or from the Cambridge Crystallographic Data Centre (CCDC), 12 Union Road, Cambridge CB2 1EZ, UK; fax: +44(0)1223-336033 or e-mail: deposit@ccdc.cam.ac.uk.

\section{Acknowledgments}

This research was supported by the Top-class foundation of Pingdingshan University (no. PXYBSQD-2018006 and PXY-PYJJ-2018002).

\section{References}

1. (a) M. Das, S. R. Chaudhuri, D. Basak, S. Dasgupta, D. Ray, Inorg. Chim. Acta 2019, 485, 140-154;

DOI:10.1016/j.ica.2018.10.018 (b) E. Echenique-Errandonea, A. Zabala-Lekuona, J. Cepeda, A. Rodriguez-Diequez, J. M. Seco, I. Oyarzabal, E. Colacio, Dalton Trans. 2019, 48, 190-201; DOI:10.1039/C8DT03800G (c) I. Galadzhun, R. Kulmaczewski, O. Cespedes, M. Yamada, N. Yoshinori, T. Konno, M. A. Halcrow, Inorg. Chem. 2018, 57, 13761-13771. DOI:10.1021/acs.inorgchem.8b02289

2. (a) M. Simunkova, P. Lauro, K. Jomova, L. Hudecova, M. Danko, S. Alwasel, I. M. Alhazza, S. Rajcaniova, Z. Kozovska, L. Kucerova, J. Moncol, L. Svorc, M. Valko, J. Inorg. Biochem. 2019, 194, 97-113; DOI:10.1016/j.jinorgbio.2019.02.010

(b) S. Bharti, M. Choudhary, B. Mohan, J. Coord. Chem. 2018, 71, 284-310; DOI:10.1080/00958972.2018.1424839

(c) Y.-F. Kang, X. Q. Liang, X. Wang, T. T. Si, Y. T. Chen, J. H. Zhang, J. Zhao, Inorg. Chem. Commun. 2017, 86, 218-222; DOI:10.1016/j.inoche.2017.10.028

(d) J. Joseph, G. B. Janaki, K. Nagashri, R. S. Joseyphus, J. Coord. Chem. 2017, 70, 242-260.

DOI:10.1080/00958972.2016.1250153

3. (a) M. Iqbal, S. Ali, M. N. Tahir, J. Coord. Chem. 2018, 71, 991-1002; DOI:10.1080/00958972.2018.1456655

(b) Y.-J. Sun, P. Li, Q.-Q. Huang, J.-J. Zhang, S. B. Itoh, Eur. J. Inorg. Chem. 2017, 13, 1845-1854;

DOI:10.1002/ejic.201601371

(c) A. Solanki, M. H. Sadhu, S. Patel, R. Devkar, S. B. Kumar, Polyhedron 2015, 102, 267-275;

DOI:10.1016/j.poly.2015.09.012

(d) R. N. Patel, D. K. Patel, K. K. Shukla, Y. Singh, J. Coord. Chem. 2013, 66, 4131-4143;

DOI:10.1080/00958972.2013.862790

(e) Y.-J. Ren, J.-L. Zhu, L.-X. Zhang, Y.-X. Xu, S.-S. Qian, Acta Chim. Slov. 2017, 64, 825-831;

(f) A. Mushtaq, S. Ali, M. N. Tahir, H. Ismail, B. Mirza, M. Saadiq, M. A. Haleem, M. Iqbal, Acta Chim. Slov. 2017, 64, 397-408. DOI:10.17344/acsi.2017.3250

4. P. B. Sreeja, M. R. P. Kurup, A. Kishore, C. Jasmin, Polyhedron 2004, 23, 575-581. DOI:10.1016/j.poly.2003.11.005

5. (a) N. Martini, J. E. Parente, M. E. Toledo, G. E. Escudero, C. H. Laino, J. J. M. Medina, G. A. Echeverria, O. E. Piro, L. Lezama, P. A. M. Williams, E. G. Ferrer, J. Inorg. Biochem. 2017, 174, 76-89; DOI:10.1016/j.jinorgbio.2017.05.012

(b) E. Ferrari, R. Benassi, M. Saladini, G. Orteca, Z. Gazova, K. Siposova, Chem. Biol. Drug Des. 2017, 89, 411-419; DOI:10.1111/cbdd.12847

(c) J. Joseph, K. Nagashri, G. B. Janaki, Eur. J. Med. Chem. 2012, 49, 151-163; DOI:10.1016/j.ejmech.2012.01.006 
(d) Y.-L. Sang, X.-S. Lin, Acta Chim. Slov. 2019, 66, 168-172. 6. Bruker, SMART and SAINT. Bruker AXS Inc., Madison, Wisconsin, USA, 2002.

7. G.M. Sheldrick, SADABS. Program for Empirical Absorption Correction of Area Detector, University of Göttingen, Germany, 1996.

8. G. M. Sheldrick, SHELXTL V5.1 Software Reference Manual, Bruker AXS, Inc., Madison, Wisconsin, USA, 1997.

9. A. Barry, Procedures and Theoretical Considerations for Testing Antimicrobial Agents in Agar Media, In: Antibiotics in Laboratory Medicine, Lorian, V. (Ed.), Baltimore: Williams and Wilkins, 1991.

10. (a) F.-J. Yin, G. Yu, H. Zhao, D.-S. Bai, Acta Crystallogr. 2012, E68, m350; (b) R. E. Marsh, Acta Crystallogr. 2005, B61, 359; (c) H.-T. Xia, Y.-F. Liu, S.-A. Li, Acta Crystallogr. 2006, E62, m2653; (d) F.-J. Yin, H. Zhao, X.-Y. Xu, X.-J. Yang, Chin. J.
Inorg. Chem. 2012, 28, 1700-1704; (e) Y.-Q. Jiang, X.-F. Yu, Chin. J. Struct. Chem. 1992, 11, 261-265.

11. (a) F.-J. Yin, L.-J. Han, S.-P. Yang, X.-Y. Xu, Y. Gu, Acta Crystallogr. 2011, E67, m1821; (b) F.-J. Yin, L.-J. Han, S.-P. Yang, X.-Y. Xu, Acta Crystallogr. 2011, E67, m1772.

12. S. Manna, E. Zangrando, H. Puschmann, S. C. Manna, Polyhedron 2019, 162, 285-292.

DOI:10.1016/j.poly.2019.01.057

13. (a) D.-Y. Ma, Inorg. Chim. Acta 2012, 392, 440-445; DOI:10.1016/j.ica.2012.05.023

(b) R. Carballo, A. Castineiras, S. Balboa, B. Covelo, J. Niclos, Polyhedron 2002, 21, 2811-2818.

DOI:10.1016/S0277-5387(02)01289-5

14. J. W. Searl, R. C. Smith, S. Wyard, J. Proc. Phys. Soc. 1961, 78, 1174-1181. DOI:10.1088/0370-1328/78/6/311

\section{Povzetek}

Sintetizirali in okarakterizirali smo dva nova bakrova(II) kompleksa, $\left[\mathrm{CuL}_{2}(\mathrm{EA})\right](\mathbf{1})$ in $\left[\mathrm{Cu}_{2} \mathrm{~L}_{4}(\mathrm{PA})_{2}\right] \cdot 2 \mathrm{H}_{2} \mathrm{O}\left(\mathbf{2} \cdot 2 \mathrm{H}_{2} \mathrm{O}\right)$, kjer je L 1-naftilacetat, EA je N,N-dietiletan-1,2-diamin in PA je propan-1,3-diamin. Strukturi kompleksov smo določili z rentgensko monokristalno analizo. Kompleks 1 je enojedrna bakrova(II) spojina z Cu atomom koordiniranim s kvadratno planarno geometrijo. Kompleks $2 \cdot 2 \mathrm{H}_{2} \mathrm{O}$ je centrosimetrična dvojedrna bakrova(II) spojina z Cu atomom koordiniranim s kvadratno piramidalno geometrijo. Kristalna struktura je stabilizirana z vodikovimi vezmi. Antimikrobne aktivnosti obeh spojin smo testirali na Staphylococcus aureus, Escherichia coli in Candida albicans. Proučili smo tudi termične lastnosti spojin.

Except when otherwise noted, articles in this journal are published under the terms and conditions of the Creative Commons Attribution 4.0 International License 